\title{
Thermal response of Sanabria Lake to global change (NW Spain)
}

\author{
Anaïs Ramos-Fuertes ${ }^{1, *}$, José Carlos $\mathrm{Vega}^{2}$, Antoni Palau ${ }^{3}$, Joan Armengol4, Antonio Casaso- \\ la ${ }^{5}$, Alejandro Rodríguez ${ }^{5}$ and Josep Dolz ${ }^{1}$ \\ ${ }^{1}$ Instituto Flumen UPC-CIMNE, Universitat Politècnica de Catalunya, C/ Jordi Girona 1-3, 08034, Barcelona, \\ Spain. \\ 2 Laboratorio de Limnología, Parque Natural del Lago de Sanabria y Alrededores, Ctra. del Lago (ZA-104), km \\ 4.75, 49360, Rabanillo-Galende, Zamora, Spain. \\ 3 Dep. Medi Ambient i Ciències del Sòl, Universitat de Lleida, Av. A. Rovira Roure 177, 25191, Lleida, Spain. \\ ${ }^{4}$ Departament de Biologia Evolutiva, Ecologia i Ciències Ambientals, Universitat de Barcelona, Diagonal, 643, \\ 08028 Barcelona, Spain. \\ ${ }^{5}$ Endesa, S.A., Ribera del Loira, 60-3A, 28042 Madrid, Spain. \\ *Corresponding author: anais.ramos@upc.edu
}

Received: 16/11/18 Accepted: 26/09/19

\begin{abstract}
Thermal response of Sanabria Lake to global change (NW Spain)

Are large water bodies able to act as sensors of global change? As accumulators of water and heat, some of their thermal characteristics might be altered by long term (decadal) hydrometeorological changes and thus may be used as indicators of the effects of global change on fluvial ecosystems. This work focuses on the effect of global change (climate change plus water quantity and land use changes) in the internal organization of Sanabria Lake, specifically in its thermal annual cycle. The existence of temporal trends in the thermal behaviour of the lake was investigated based on the water temperature profiles that are available since 1986. Data analyses include the non-parametric Mann-Kendall trend test and the Sen slope estimate to evaluate long term and seasonal patterns of hydrometeorological and in-lake thermal variables. The main results surprisingly point to a net lake cooling that could be explained by a stronger thermocline and a weaker vertical transfer of heat to the hypolimnion during the stratification period. These results contribute to understand and quantify the effects of global change on Iberian freshwater bodies.
\end{abstract}

Key words: thermal stability, stratification period, water temperature, global change, Sanabria Lake

\section{RESUMEN}

\section{Respuesta térmica del lago de Sanabria al cambio global (NO España)}

¿Pueden ser las grandes masas de agua sensores de cambio global? Como acumuladoras de agua y calor, algunas de sus características térmicas podrían verse alteradas por cambios hidrometeorológicos a medio y largo plazo y así ser utilizadas como indicadoras de los efectos del cambio global sobre los ecosistemas fluviales. Este trabajo se centra en el estudio de la incidencia de cambio global (cambio climático más cambio de usos de agua y suelo) en la organización interna del lago de Sanabria, concretamente en su ciclo anual térmico. Se estudia la existencia de tendencias temporales en el comportamiento térmico del lago, donde se dispone de perfiles de temperatura del agua desde el año 1986. Los análisis de datos incluyen las técnicas estadísticas no paramétricas del test de tendencia de Man-Kendall y la estimación de pendiente de Sen para evaluar patrones estacionales y a largo plazo de variables hidrometeorológicas y térmicas del lago. Los resultados principales indican que, sorprendentemente, el lago de Sanabria se está enfriando globalmente, lo cual podría explicarse por un fortalecimiento de la termoclina y un descenso de la transferencia de calor al hipolimnion durante el periodo de estratificación. Estos resultados contribuyen a entender y cuantificar la susceptibilidad de las masas de agua ibéricas al cambio global.

Palabras clave: estabilidad térmica, periodo de estratificación, temperatura del agua, cambio global, lago de Sanabria 


\section{INTRODUCTION}

The physical characteristics and ecological functioning of freshwater bodies are highly conditioned by their hydroclimatic context and the human activities developed in their catchment area, and thus they are expected to be sensitive to changes in these conditions. Since water temperature and density are closely related, the exchange of heat with the environment influences the hydrodynamics of a water body, and consequently affects the internal circulation of nutrients and the connectivity of different depths in the water column. Besides, the metabolism, physiology, and behaviour of aquatic organisms are directly related to the temperature of the aquatic environment (Wetzel \& Likens, 2000). As a result, water quality and ecology of a lake and the downstream river are strongly affected by the lake thermal characteristics, such as the stratification and overturn pattern. These thermal characteristics mainly depend on the climatic conditions, the quality and quantity of the water inflows and the lake basin morphometry.

The global change, defined as the climate change plus land and water use changes, has been shown to affect the thermal structure of lakes. Recent studies point to a higher thermal stability of large lakes due to climate change (Sahoo et al., 2016), a deep water warming (in Alpine lakes; Ambrosetti \& Barbanti, 1999). and there is a general consensus on the increase of inland water surface temperature (Dokulil, 2014b).

In the Iberian Peninsula, where reservoirs are much more frequent than lakes, the effects of the global change on the water quantity and quality of reservoirs and the changes in the thermal regime of rivers are considered as two of the main environmental challenges of reservoir management (Prats Rodríguez et al., 2014). The potential effects of global change are thought to increase the risk of eutrophication in reservoirs (Palau \& Prieto, 2009), where selective water withdrawal elevation may be of great interest to control the transfer of heat and constituents in the dam, in particular during the thermal stratification period (Armengol et al., 2009).

Evidences of global change impacts on freshwater bodies in Spain include increasing water temperatures, thermal stability, and the consequent biochemical responses. In the Pyrenees, Lake Redó has increased its temperature during the $20^{\text {th }}$ century, as a response of increasing summer and autumn air temperatures (Catalan et al. 2002). In this region, lake ecosystems are known to be highly dependent on ice cover duration (Catalan et al., 2009). Recent analyses by Sabater et al. (2016) point out a higher thermal stability and surface warming of Lake Banyoles (Girona, Spain). The Sau Reservoir (Ter River, Barcelona, Spain) has shown a relationship between a decrease in water inflows and deep anoxic conditions (Marcé et al., 2010), which are also known to depend on the stratification pattern. However, a deep understanding of the freshwater bodies response to global change is still far from being achieved, since long-term field data are scarce and the system response is dependent on particular conditions, such as the water body morphometry (Kraemer et al., 2015).

Lakes and reservoirs can provide valuable information on how terrestrial and aquatic ecosystems are responding to climate and global change (Williamson et al., 2009). This study contributes to quantify the susceptibility of Iberian water bodies to these changes. It focuses on the evaluation of recent temporal trends in the thermal behaviour of Sanabria Lake by analysing limnological data collected in the period 1986-2016. The quantification of the recent trends in the physical response of Sanabria Lake helps to understand the role of Iberian waterbodies as sensors or sentinels to global change.

\section{STUDY AREA AND METHODS}

\section{Study area}

Sanabria Lake $\left(42^{\circ} 07^{\prime} 30^{\prime \prime} \mathrm{N}, 06^{\circ} 43^{\prime} 00^{\prime \prime} \mathrm{W}\right)$ is located at $1000 \mathrm{~m}$ a.s.l. in a glacial depression of the Tera River catchment (Zamora, NW Spain), in the Duero River Basin (Fig. 1). It is the largest natural freshwater lake of the Iberian Peninsula regarding volume and has an area of $3.2 \mathrm{~km}^{2}$, a drainage area of $127.3 \mathrm{~km}^{2}$ and $96.3 \mathrm{hm}^{3}$ of capacity, with a maximum depth of $51 \mathrm{~m}$ (Vega et al., 2005). The Tera River constitutes the main 


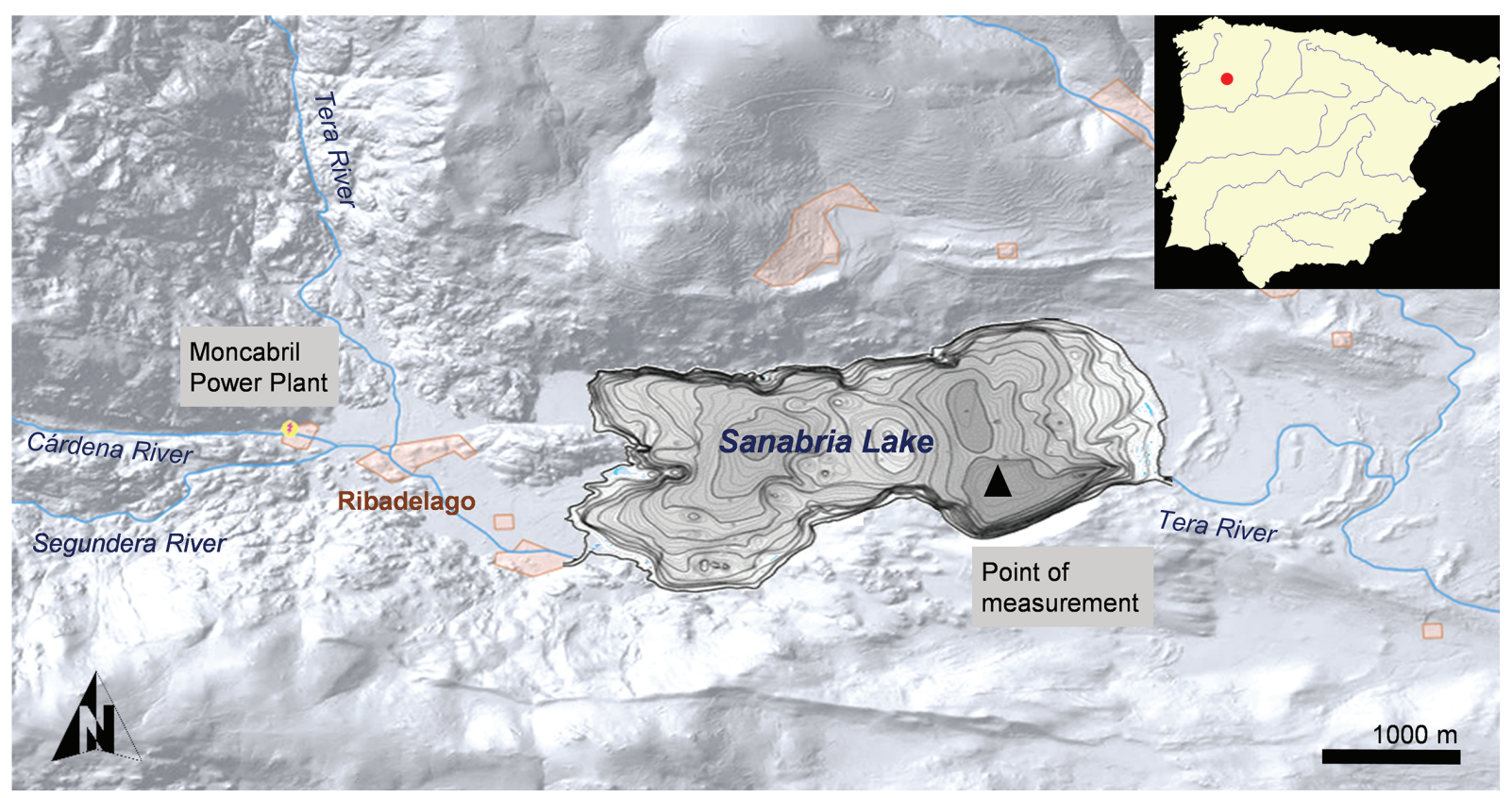

Figure 1. Study area. Área de estudio.

inflow to the lake (only complemented by small streams that drain direct runoff) and its only outflow. Upstream of the lake, there are several small dams related to the Moncabril power plant that have a limited influence on the Tera River hydrology (Giralt et al., 2011). Average lake inflow in the period 1986-2016 is 10.9 $\mathrm{hm} 3 /$ month, with a seasonal maximum of 18.0 $\mathrm{hm}^{3} /$ month in December and a minimum of 3.2 $\mathrm{hm}^{3} / \mathrm{month}$ in August (Fig. 2).

As shown by Vega et al. (1992), the thermal behaviour of Sanabria Lake is warm monomictic, with a winter mixing circulation between $4-7^{\circ} \mathrm{C}$ and a typical stratification period from March to early December. Regarding the lake water transparency, the same authors characterise Sanabria as oligotrophic, with seasonal Secchi disc depths ranging from 5 to 9 meters. Seasonal maximum turbidity is related to winter rainfalls and the maximum transparency occurs in late summer.

\section{Data}

Monthly data series from 1986 to 2016 were provided by the Laboratory of Limnology of the Sanabria Lake Natural Park, including: mea- sured water temperature profiles, air temperature and precipitation in Ribadelago (the nearest village, $1 \mathrm{~km}$ from the lake) and in the catchment area, Moncabril power plant discharge, total inflow to the lake and measured inflow water temperature. Lake water temperature profiles (373 in total) were available at $0,2.5$ and $5 \mathrm{~m}$ depth and $5 \mathrm{~m}$ vertical intervals from 5 to $50 \mathrm{~m}$ depth (Fig. 1). During the study period, the measurement location was not changed and the different instruments used were verified against a certified thermometer. Hypsometric data were also available at $1 \mathrm{~m}$ depth intervals from the same data source.

\section{Methods}

Long-term trends were analysed based on 27 study variables describing the hydrometeorological context, water temperature, thermal stability and stratification period of Sanabria Lake. Table 1 contains the variables of study, their nomenclature and their estimation method or reference. Some of them have been estimated using the Lake Analyzer tool (Read et al., 2011), as noted in Table 1. 

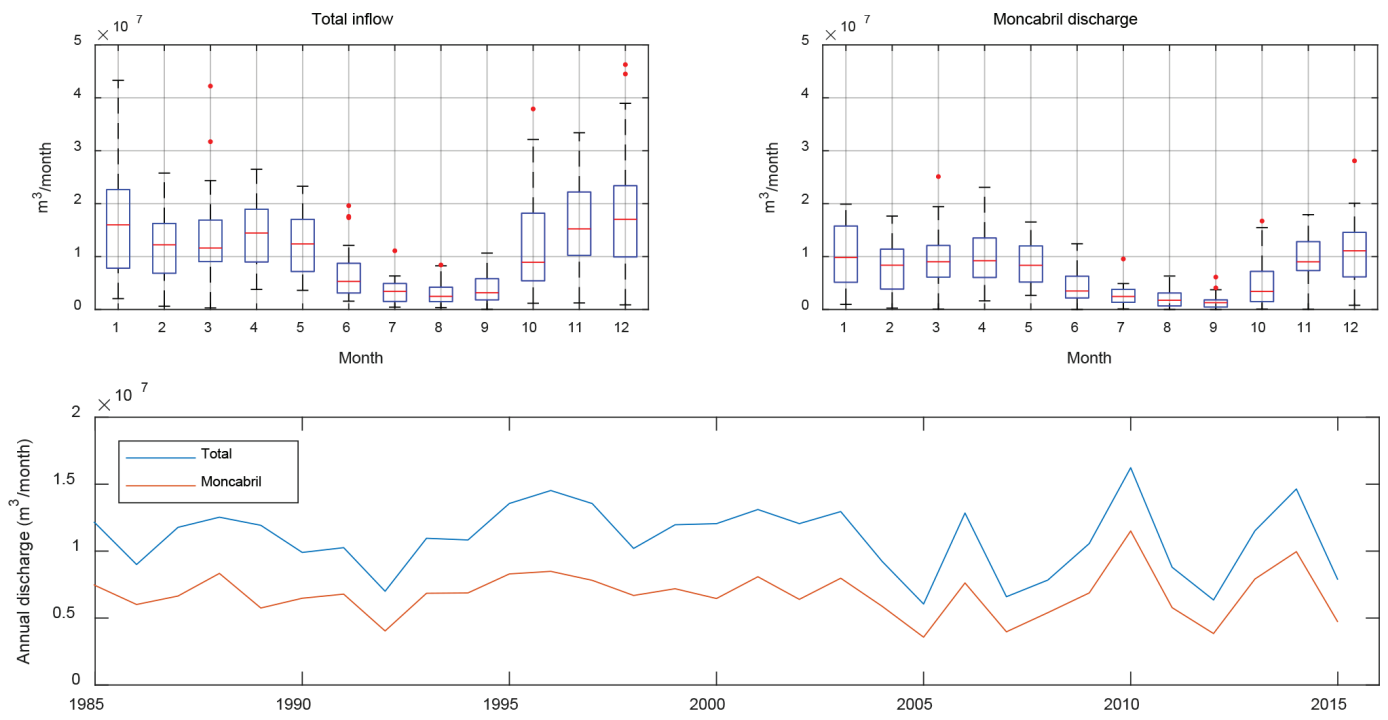

Figure 2. Lake Sanabria total inflow and Moncabril power plant discharge. Monthly boxplots (upper) and annual means (lower). Caudal total de entrada al lago de Sanabria y turbinado por la central hidroeléctrica de Moncabril. Diagramas de caja mensuales (superior) y promedios anuales (inferior).

Table 1. Study variables, nomenclature and estimation methods or references. Variables de estudio, nomenclatura y métodos o referencias de estimación.

\begin{tabular}{|c|c|c|c|}
\hline$\overline{\text { Group }}$ & Variable & Nomenclature & Estimation method or reference \\
\hline \multirow{8}{*}{ 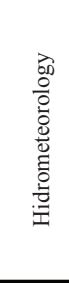 } & Mean air temperature & TaMn & Average of TaMax and TaMin \\
\hline & Maximum air temperature & TaMax & Source data \\
\hline & Minimum air temperature & TaMin & Source data \\
\hline & Precipitation & Ppt & Source data \\
\hline & Total inflow & Qin & Source data \\
\hline & Power plant discharge & Qpp & Source data \\
\hline & Hydraulic residence time & Tresid & Tresid $=$ Lake volume/Qin \\
\hline & Heat inflow & Hin & $\operatorname{Hin}=\rho C w \operatorname{Qin} \operatorname{TwIn}(* *)$ \\
\hline \multirow{7}{*}{ 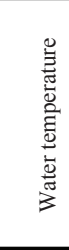 } & Mean & TwMn & Average water temperature ( 0 to $50 \mathrm{~m}$ depth) \\
\hline & Volumetric & TwVol pond & Weighted mean of water temperature with volume \\
\hline & Surface & TwSf & Source data. Measured at $5 \mathrm{~m}$ depth. \\
\hline & Bottom & TwBt & Source data. Measured at $45 \mathrm{~m}$ depth. \\
\hline & Epilimnion $(*)$ & TwEpi & Average temperature above thermocline \\
\hline & Hypolimnion $(*)$ & TwHypo & Average temperature below thermocline \\
\hline & Inflow & TwIn & Source data \\
\hline \multirow{4}{*}{ 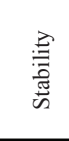 } & Schmidt stability index & St & Read et al., 2011 \\
\hline & Maximum Brunt-Väisälä frequency & N2 & Read et al., 2011 \\
\hline & Maximum St & StMax & Maximum daily St \\
\hline & Day of maximum St & StMaxD & Day of year of maximum St \\
\hline \multirow{7}{*}{ 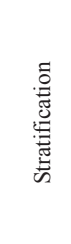 } & Day of stratification & StrStart & Day of year when $\mathrm{St}>52 \mathrm{~J} / \mathrm{m}^{2}$ \\
\hline & Day of mixing & StrEnd & Day of year when $\mathrm{St}<52 \mathrm{~J} / \mathrm{m}^{2}$ \\
\hline & Duration & Str & Str $=$ StrEnd - StrStart +1 \\
\hline & Thermocline depth $(*)$ & thermD & Read et al., 2011 \\
\hline & Metalimnion bottom depth $(*)$ & metaB & Read et al., 2011 \\
\hline & Metalimnion top depth $(*)$ & metaT & Read et al., 2011 \\
\hline & Metalimnion thickness $(*)$ & meta & meta $=$ metaT - metaB \\
\hline
\end{tabular}


In order to avoid the influence of the daily surface stratification, and therefore the influence of the hour of measurement on lake surface temperature trends, surface temperatures are defined as water temperature measurements at 5 $\mathrm{m}$ depth. In the same way, bottom water temperatures are defined as water temperatures at $45 \mathrm{~m}$ depth to avoid possible errors derived from the contact of the instrumentation with the lake bottom.

Seasonality was removed from monthly variables before statistical analyses were performed. Taking into account the influence of the day of measurement, seasonal patterns of the study variables derived from field campaigns data (all in Table 1 except hydrometeorology) were estimated by a LOWESS filter against day of year (Helsel \& Hirsch, 2002). Seasonal patterns of hydrometeorological data, which actually represent the month of reference, were estimated by monthly medians.

Some study variables, such as the days of year when lake stratification or mixing occurs, require a more detailed temporal discretization. In such cases, daily lake water temperatures were estimated by a cubic spline interpolation of monthly measurements at each depth. Using these daily estimations, for the purposes of the present study, the stratification period is defined as the period above a threshold of lake thermal stability of $52 \mathrm{~J} / \mathrm{m}^{2}$, which corresponds to a mean surface-bottom water temperature difference of 1 ${ }^{\circ} \mathrm{C}$ in the historical data.

Temporal trends were evaluated by the non-parametric statistical test of Mann-Kendall and the magnitude of the temporal changes was obtained by the Sen slope estimate (Helsel \& Hirsch, 2002). In each study variable, trend tests were performed for the complete time series and also for each meteorological season: winter (December to February), spring (March to May), summer (June to August) and autumn (September to November). Study variables depending on the thermocline depth are only evaluated in the period June-October, as noted in Table 1.

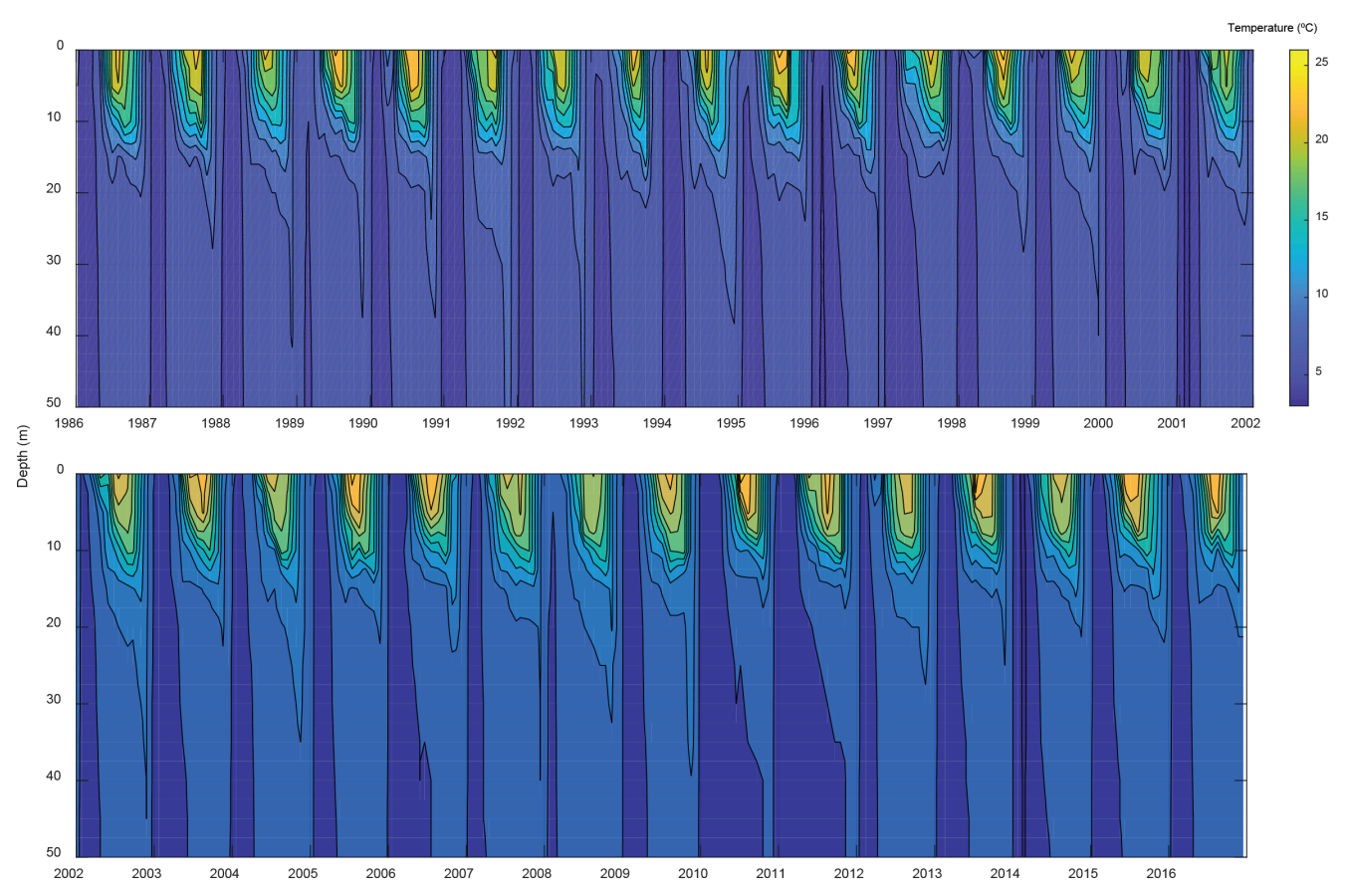

Figure 3. Vertical water temperature profiles in Sanabria Lake $\left({ }^{\circ} \mathrm{C}\right)$ in the period 1986-2016. Isolines every $2{ }^{\circ} \mathrm{C}$. Perfiles verticales de temperatura del agua en el lago de Sanabria $\left({ }^{\circ} \mathrm{C}\right)$ en el periodo 1986-2016. Isolíneas cada $2{ }^{\circ} \mathrm{C}$. 


\section{RESULTS}

\section{Average thermal characteristics of Lake Sanabria}

The estimated seasonal patterns of the study variables define the average thermal properties of Sanabria Lake during the period of study 1986-2016, as shown in Figure 2. Average water column temperature is $7.9^{\circ} \mathrm{C}$, with a seasonal variation from $4.8^{\circ} \mathrm{C}$ in February (winter mixing) to $10.3{ }^{\circ} \mathrm{C}$ in late August (summer stratification), with a higher variability in winter than in summer. Average volume-weighted temperatures, where surface layers have a greater relative importance, are identical to the former during the winter mixing and reach a maximum of $12.0^{\circ} \mathrm{C}$ in summer. Surface temperatures (measured at 5 $\mathrm{m}$ depth) present a higher variability and reach a maximum of $21.0{ }^{\circ} \mathrm{C}$ in early August, while bottom temperatures $(45 \mathrm{~m}$ depth) reach a maximum of $7.3{ }^{\circ} \mathrm{C}$ in late November, after the lake mixing occurs. The mean inflow temperature is $10.5^{\circ} \mathrm{C}$.

The Schmidt thermal stability index is defined as the amount of work needed to mix the entire water body to uniform temperature without addition or subtraction of heat. In Sanabria Lake, the thermal stability is almost negligible from November to March and reaches its maximum $\left(1.83 \mathrm{~kJ} / \mathrm{m}^{2}\right)$ in mid-August. According to the daily estimates of this index, the average lake stratification period lasts 222 days, from $15^{\text {th }}$ April until 21 st November. The thermocline deepens from $5.7 \mathrm{~m}$ in June to $14.6 \mathrm{~m}$ in late October, with its maximum strength or local thermal stability (Brunt-Väisälä frequency) in late July.

\section{Evaluation of temporal trends in Sanabria Lake}

Table 2 and Figure 5 resume the results of the evaluation of temporal trends in the study variables, in units per decade and in percentages relative to their average value.

Regarding the local hydrometeorological context of Sanabria Lake, there is a strong statistical evidence ( $p$-value $<0.0001$ ) of an increase in monthly mean and maximum air temperatures of
0.32 and $0.74{ }^{\circ} \mathrm{C} /$ decade, respectively. Seasonally, mean air temperatures are higher in spring $(0.59$ ${ }^{\circ} \mathrm{C} /$ decade $)$ and summer $\left(0.67^{\circ} \mathrm{C} /\right.$ decade $)$, while maximum air temperatures increase in spring (1.01 ${ }^{\circ} \mathrm{C} /$ decade), summer $\left(1.29^{\circ} \mathrm{C} /\right.$ decade $)$ and autumn $\left(0.70{ }^{\circ} \mathrm{C} /\right.$ decade $)$. No significant trends are found in winter air temperatures nor in minimum air temperatures. Precipitations and river inflow show less significant decreases of about $5 \%$ of their average magnitude per decade in the complete data series ( $p$-values $<0.1$ and $<0.05$, respectively) but no significant seasonal trends. Regulated lake inflow (or power plant discharge) presents a decrease in summer of about $11 \%$. Accordingly, lake water residence time presents global (2\%) and summer $(10 \%)$ increases.

Lake water temperatures present temporal trends of high statistical significance and opposite sign depending on depth. Surprisingly, deep water temperatures register decreases of high and excellent statistical significance all over the year except in the winter mixing. Hypolimnetic temperatures from June to October register a more intense cooling of excellent reliability. This comparison indicates that the upper hypolimnion is cooling more intensively than the lower hypolimnion. Surface temperatures are found to increase only in autumn $\left(0.48^{\circ} \mathrm{C} /\right.$ decade $)$, while epilimnion temperatures do not present any significant temporal trend (Fig. 3 ).

As a result of the deep waters cooling, average lake water column temperatures decrease 0.10 ${ }^{\circ} \mathrm{C} /$ decade with high statistical significance ( $p$-value $<0.01$ ). Seasonally, this cooling is more intense and reliable in summer lake temperatures, but is also found in spring and autumn (Fig. 4). Volumetric temperatures, which are more dependent on surface than deep waters, present similar results than depth-averaged temperatures with less intensity and significance of trends. River Tera temperatures do not register significant trends at the lake entrance.

Regarding the thermal structure of the lake, the most important trend found in an increase of the thermocline local stability (or Brunt-Väisälä frequency), from spring to autumn. Globally, this variable increases $5.65 \%$ of its mean value per decade. According to a more stable thermocline, the lower limit of the metalimnion from June to 

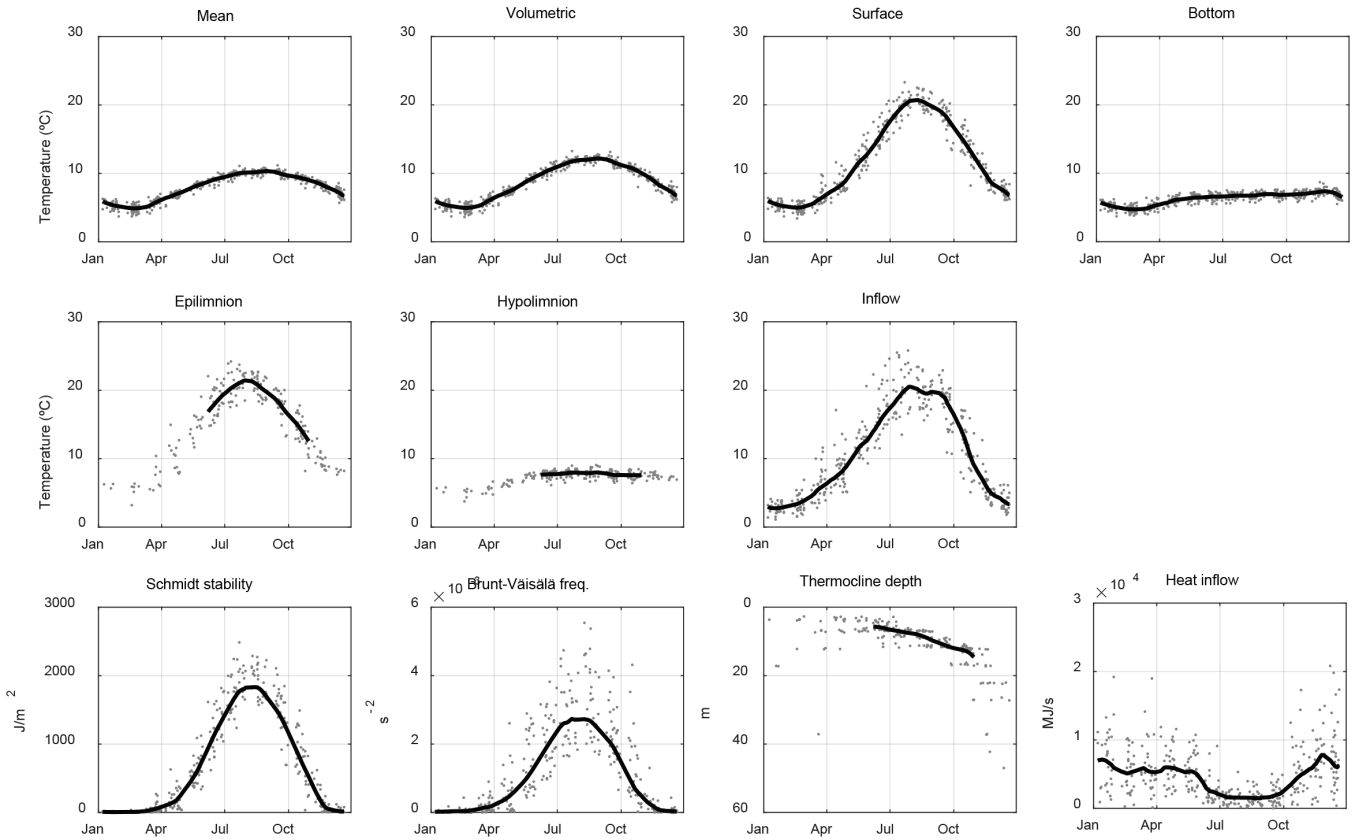

Figure 4. Seasonal patterns of the principal thermal variables of Lake Sanabria. Points are punctual estimations from the 1986-2016 dataset and lines are the seasonal evolution obtained by a LOWESS smoothing. Patrones estacionales de las principales variables térmicas del lago de Sanabria. Los puntos indican las estimaciones a partir de datos de campo del periodo 1986-2016 y las líneas los patrones medios estacionales obtenidos por la técnica LOWESS.

October significantly shifts its position upwards. The thermal stability of the entire water column (Schmidt stability index) is increasing only in autumn and, consequently, the lake mixing that occurs in this season is delayed 3 days per decade.

\section{DISCUSSION}

\section{Methodological approach}

To the authors' knowledge, this is the first study describing the average characteristics and recent trends of Sanabria Lake thermal properties. In order to maximize the comparability of the results, widespread methods such as the freely available Lake Analyzer tool have been chosen (Read et al., 2011). However, there is no consensus on the estimation of particular variables, such as the stratification period. Different studies can be found where this period is defined by a specific surface-bottom water temperature difference or by a thermal stability threshold. Since both criteria are positively correlated $\left(\mathrm{R}^{2}=0.94\right.$ in Sanabria Lake historical data), this study proposes a thermal stability threshold that corresponds to a mean surface-bottom temperature difference of 1 ${ }^{\circ} \mathrm{C}$ in the historical record. A different threshold would lead to systematically estimate longer or shorter periods of stratification, but would not affect the evaluation of temporal trends (Stainsby et al., 2011; Engelhardt \& Kirillin, 2014).

The historical record of Sanabria Lake is of great value to study its recent limnological trends. However, monthly measurements are representative of a short temp around the field campaign date. In this situation, care must be taken in the data analyses to prevent from trend biases caused by the dependence on the day of measurement (Sahoo et al., 2016). For that purpose, data seasonal detrending is made on a daily basis (not monthly nor seasonal) in the present study, and the dates of the onset and breakup of summer thermal stratification are calculated using daily 
water temperature estimations. A higher uncertainty remains on the River Tera temperature results (TwIn in Table 1), since abrupt changes in the Moncabril power plant discharge might not be registered by punctual measurements.

Regarding the statistical methods used, the non-parametric Man-Kendall trend test evaluates the presence/absence of monotonic trends in the study variables. If they are not found, it does not mean they do not exist. In some cases, variability may be too great for the statistical method to detect them. A monotonic upward (downward) trend means that the variable consistently increases (decreases) through time, but the trend may or may not be linear. When a monotonic trend is found, the Sen method is used to estimate the slope of the trend if it was linear. However, cyclic (upward and downward) trends might not be identified and the slope estimations have to be understood as an estimation of the change in time for the whole data series if it was linear, which is not necessarily the case.

\section{Local hydro-climatic trends}

Sanabria Lake is a hydrologically-open lake where limnological fluctuations are strongly linked to the Tera River discharge (Jambrina-Enríquez et al., 2017), which is highly determined by rainfall (Giralt et al., 2011). As shown by the recent review of Vicente-Serrano et al. (2017), there is a dominant negative trend of recent precipitations in mainland Spain with complex regional patterns of change. In this study, local precipitations in Ribadelago and lake inflow show a global decreasing temporal trend of $5 \%$ per decade but no significant seasonal trends. If the general trend is accepted, the incoherence
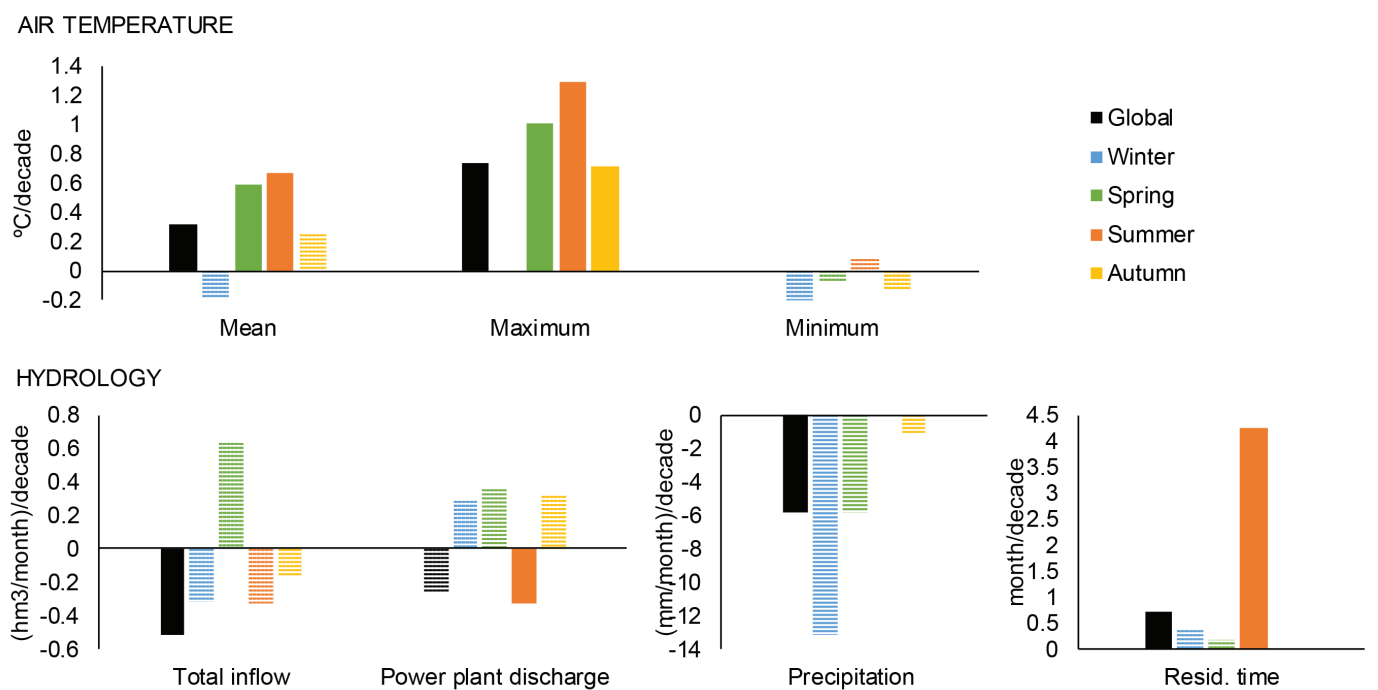

WATER TEMPERATURE

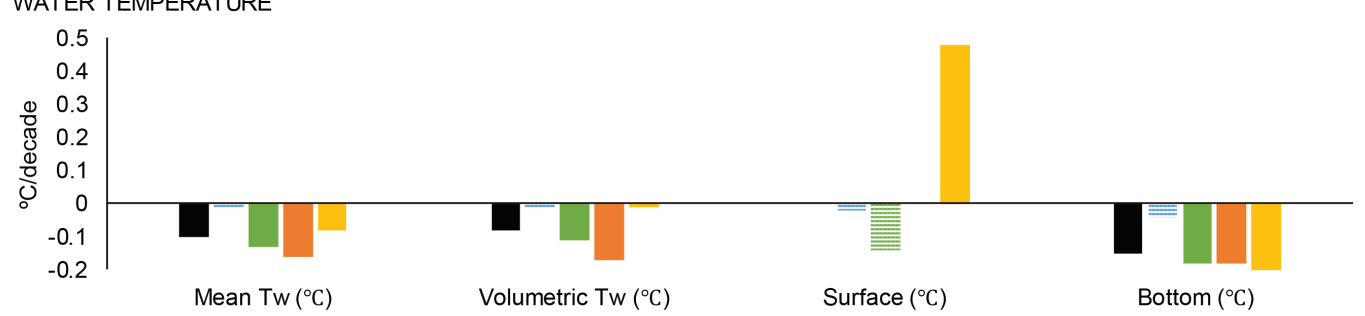

Figure 5. Main global and seasonal climatic, hydrological and thermal trends of Sanabria Lake. Solid bars represent trends with $p$-value $<0.1$. Principales tendencias climáticas, hídricas y térmicas del lago de Sanabria, globales y estacionales. Las barras sólidas indican tendencias con p-valor $<0.1$. 
might indicate that the periods contributing to the general trend are shorter than a quarterly season or that there is too much variability at the seasonal scale and the method cannot detect the seasonal trends. Morán-Tejeda et al. (2011) evaluated temporal trends in monthly precipitations in the Duero basin (1961-2006), showing only significant trends in the Sanabria area in February (decreasing) and August (increasing), being more significant the decrease in February. For a similar period (1961-2004), del Río et al. (2009) found a significant rainfall decrease in February and March and a smaller significant increase in May for the Castilla y León region, while seasonal and annual trends were not significant. Furthermore, the present study points to a decrease of the summer power plant discharge to the Tera River, which indicates a change in the power plant management criteria. Globally, a lower Tera River discharge into Sanabria Lake increases the hydraulic residence time and might reinforce the lake thermal stability, according to the results obtained in this study (Table 2).

Besides climatic and water use changes, recent land use changes in the upper Tera River catchment might also be possible but are not addressed in this work. Despite specific references regarding Lake Sanabria catchment area have not been found, Morán-Tejeda et al. (2012) found that vegetation cover has increased significantly in the headwaters of the Spanish Duero Basin since the middle of the twentieth century, as a consequence of the abandonment of pastures and crops and their replacement by natural vegetation and reforestation. These changes in the Duero Basin are representative of a generalized process of revegetation in most headwater areas of the Iberian Peninsula (Hill et al., 2008).

The general trend of warming air temperatures in the Ribadelago dataset is consistent with the recent global temperature evolution (Stocker et al., 2013). However, comparisons have to be

Table 2. Temporal trends estimated in the hydrometeorology and thermal behaviour of Sanabria Lake, in: units per decade (percentage of the mean value) $p$-value. Colour indicates positive trends (orange) or negative trends (blue) with $p$-value $<0.1$. ne: not evaluated. Tendencias temporales en la hidrometeorología y el comportamiento térmico del lago de Sanabria, en unidades por década (porcentaje de la media) y p-valor. ne: no evaluada. El color indica tendencia ascendente (naranja) o descendente (azul) con p-valor $<0.1$.

\begin{tabular}{|c|c|c|c|c|c|c|}
\hline Group & Variable (units) & Global & Winter & Spring & Summer & Autumn \\
\hline \multirow{8}{*}{ 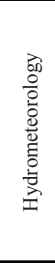 } & Mean air temp $\left({ }^{\circ} \mathrm{C}\right)$ & $0.32(3 \%) 0.0001$ & -0.180 .2340 & $0.59(6 \%) 0.0028$ & $0.67(4 \%) 0.0000$ & 0.250 .1164 \\
\hline & Max air temp $\left({ }^{\circ} \mathrm{C}\right)$ & $0.74(4 \%) 0.0001$ & 0.000 .9949 & $1.01(6 \%) 0.0004$ & $1.29(5 \%) 0.0000$ & $0.71(4 \%) 0.0028$ \\
\hline & Min air temp $\left({ }^{\circ} \mathrm{C}\right)$ & $0.00(0 \%) 0.9328$ & -0.200 .2352 & -0.080 .4474 & 0.080 .5391 & -0.140 .4287 \\
\hline & Precipitation (mm) & $-5.83(-5 \%) 0.0609$ & -13.180 .1844 & -5.870 .4718 & -3.970 .1671 & -1.050 .9037 \\
\hline & Resid. time (month) & $0.73(2 \%) 0.0622$ & 0.370 .3533 & 0.170 .6921 & $4.25(10 \%) 0.0378$ & 0.000 .9976 \\
\hline & Total inflow (hm³/month) & $-0.51(-5 \%) 0.0401$ & -0.320 .7026 & 0.630 .2428 & -0.330 .1917 & -0.170 .8539 \\
\hline & PP inflow (hm ${ }^{3} /$ month) & $-0.26(-3 \%) \quad 0.1317$ & 0.290 .5806 & 0.360 .2764 & $-0.33(-11 \%) 0.0927$ & 0.320 .2344 \\
\hline & Heat inflow $(\mathrm{MJ} / \mathrm{s})$ & $-89.94(\%) 0.4546$ & -226.20 .4749 & 184.00 .6355 & $-238.7(-12 \%) 0.0485$ & -75.870 .8235 \\
\hline \multirow{7}{*}{ 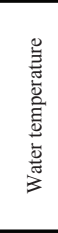 } & Mean Tw $\left({ }^{\circ} \mathrm{C}\right)$ & $-0.10(-1 \%) 0.0003$ & -0.010 .8754 & -0.130 .0137 & -0.160 .0015 & -0.080 .0850 \\
\hline & Volumetric Tw $\left({ }^{\circ} \mathrm{C}\right)$ & $-0.08(-1 \%) 0.0143$ & -0.010 .9271 & -0.110 .0814 & -0.170 .0022 & -0.010 .9075 \\
\hline & Surface $\left({ }^{\circ} \mathrm{C}\right)$ & 0.050 .4151 & -0.020 .8523 & -0.140 .4030 & -0.040 .7601 & 0.480 .0055 \\
\hline & Bottom $\left({ }^{\circ} \mathrm{C}\right)$ & $-0.15(-2 \%) 0.0000$ & -0.040 .5632 & -0.180 .0061 & -0.180 .0084 & -0.210 .0010 \\
\hline & Inflow $\left({ }^{\circ} \mathrm{C}\right)$ & -0.130 .1772 & -0.200 .1080 & -0.140 .5749 & -0.520 .1584 & 0.330 .2564 \\
\hline & Epilimnion $\left({ }^{\circ} \mathrm{C}\right)$ & 0.010 .5405 & ne & ne & ne & ne \\
\hline & Hypolimnion $\left({ }^{\circ} \mathrm{C}\right)$ & $-0.25(-3 \%) 0.0000$ & ne & ne & ne & ne \\
\hline \multirow{4}{*}{ 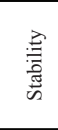 } & Schmidt stability & 7.240 .1637 & -0.620 .5478 & 4.960 .6734 & -11.070 .7576 & 80.140 .0016 \\
\hline & Brunt-Väisäla freq. $\left(\mathrm{s}^{-2}\right)$ & $6.50 \mathrm{E}-05(6 \%) 0.0001$ & $-0.17 \mathrm{E}-050.5455$ & $7.80 \mathrm{E}-050.0918$ & $2.90 \mathrm{E}-040.0081$ & $1.80 \mathrm{E}-040.0001$ \\
\hline & $\operatorname{Max} \operatorname{St}\left(\mathrm{J} / \mathrm{m}^{2}\right)$ & -31.320 .5406 & ne & ne & ne & ne \\
\hline & Day of max St (DOY) & 1.050 .8382 & ne & ne & ne & ne \\
\hline \multirow{7}{*}{ 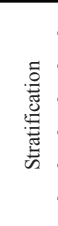 } & Day of stratification (DOY) & -0.030 .4339 & ne & ne & ne & ne \\
\hline & Mixing (DOY) & 3.330 .0948 & ne & ne & ne & ne \\
\hline & Duration (days) & 7.000 .2146 & ne & ne & ne & ne \\
\hline & Thermocline depth (m) & -0.070 .6322 & ne & ne & ne & ne \\
\hline & Metalimnion bottom (m) & $-0.48(-4 \%) 0.0000$ & ne & ne & ne & ne \\
\hline & Metalimnion top (m) & -0.170 .3003 & ne & ne & ne & ne \\
\hline & Metalimnion thickness (m) & -0.260 .0938 & ne & ne & ne & ne \\
\hline
\end{tabular}


careful, taking into account regional differences (Vicente-Serrano et al., 2017) and temporal windows (Gonzalez-Hidalgo et al., 2016). The results presented here about the increase of mean air temperatures $\left(0.32{ }^{\circ} \mathrm{C} /\right.$ decade $)$ in the period 1986-2016 are located between an increase of almost $0.5^{\circ} \mathrm{C} /$ decade reported during 1973-2005 for the Iberian Peninsula (Bladé \& Castro-Díez, 2010) and the increase of $0.14{ }^{\circ} \mathrm{C} /$ decade reported by del Río et al. (2009) for the Castilla y León region during 1961-2004.

\section{Lake Sanabria water temperature trends}

According to the results presented here (Table 2), there is an excellent statistical confidence ( $p$-value $<0.001$ ) of a decrease in the hypolimnetic and deep water temperatures of Sanabria Lake from spring to autumn in the last three decades (1986-2016). Since surface waters only present a warming trend in autumn and epilimnetic temperatures do not significantly change, the lake depth-averaged and volume-averaged water temperatures are also decreasing $\left(-0.10^{\circ} \mathrm{C} /\right.$ decade and $-0.08{ }^{\circ} \mathrm{C} /$ decade, respectively). These thermal trends differ from the general warming trends in European lakes (Dokulil, 2014a). Arvola et al. (2009) reported long-term temperature changes of 19 lakes from Finland, UK, Austria and Switzerland with data belonging to the period 1961-2006. On average, surface and bottom water temperatures increased $0.36{ }^{\circ} \mathrm{C} /$ decade and $0.03{ }^{\circ} \mathrm{C} /$ decade, respectively, although the response was dependent on lake type and only $40 \%$ of the trend tests had $p$-values lower than 0.05 . Monomictic lakes in UK showed average summer (winter) increases of surface water temperature of $0.35(0.26){ }^{\circ} \mathrm{C} /$ decade and of $0.07(0.34){ }^{\circ} \mathrm{C} /$ decade in bottom water temperatures.

In Lake Sanabria, surface temperatures do not follow the increase of mean air temperatures in spring and summer. However, the air temperature increase is asymmetrical, with only a significant warming in the daily (maximum) temperatures. Unchanged night-time (minimum) air temperatures might lead the nocturnal heat loss at the water surface towards a "thermal reset" at a daily timescale.
Hypolimnetic temperatures in warm monomictic lakes, such as Sanabria Lake, depend on winter mixing lake temperatures and on the vertical heat flux through the metalimnion during the stratification period. In Sanabria Lake, the absence of air and water thermal trends in the winter season and the strengthening of the thermocline during stratification might explain a decline in hypolimnetic and bottom water temperatures. A more stable thermocline and the upward shift of the lower limit of the metalimnion indicate that a stronger thermocline inhibits the convective transfer of heat from the surface to deep waters. Hypolimnion cooling was also found in Lake Kinneret (Israel), but the trend was linked to a long-term observed decline in winter air temperatures (Hambright et al., 1994). A similar effect of hypolimnetic cooling in small deep lakes was reported in a numerical modelling study by Hondzo and Stefan (1993), as a result of an earlier thermal stratification. More recently, Magee and $\mathrm{Wu}$ (2017) pointed to a decline in wind speed (even combined with an air temperature increase) as responsible for observed and modelled hypolimnetic cooling in two dimictic lakes in Wisconsing, USA.

\section{Thermal balance of Lake Sanabria: trends and uncertainties}

The heat content of a lake is generally driven by the thermal exchange at the air-water interface, and to a less extent by heat fluxes at the water-soil interface and by inflows and outflows (Henderson-Sellers, 1986). Assuming a constant volume of water and negligible heat fluxes at the soil-water interface in Sanabria Lake, changes in the heat content of the lake must be linked to surface heat fluxes and inflow-outflow water temperature differences. Since the water volume is considered constant, changes in the heat storage of the lake are equivalent to changes in the volume-weighed water temperature (TwVol in Table 1). At an annual scale, this study reports a decrease of $1 \%$ per decade in the volumetric water temperature ( $p$-value $<0.01)$, and no significant trends in inflow, epilimnetic and surface temperatures (Table 2). Surface and/or epilimnetic temperatures can be roughly equivalent to outflow 
temperatures, which are not measured and actually depend on density gradients and water flow. Therefore, these results indicate a net heat loss at the air-water interface with time, which could be caused by a decrease of the incident heat fluxes (mainly solar and atmospheric radiation, sensible heat from the atmosphere) or an increase of the surface heat losses (mainly evaporation and net longwave radiation). Climatic trends reported in Spain point to increases of air temperatures, solar radiation and atmospheric evaporative demand, suggesting increases of both the incident heat fluxes and the evaporative heat losses (Vicente-Serrano et al., 2017). According to the results presented here, an incremented heat flux entrance during the day at the air-water interface might contribute to the strengthening of the lake stratification (Brunt-Väisälä frecuency in Table 2), while higher surface heat losses (evaporation, longwave emission) could prevent from an epilimnetic and surface water heating. The reason why autumn water surface temperatures increase in Sanabria Lake is thus uncertain, but has important implications. According to Table 2, it is related to a highly significant increase of Schmidt thermal stability $(p$-value $<0.01)$ and a consequent delay in the water column overturn of 3 days per decade $(p$-value $<0.1)$. This increase of surface water temperatures in autumn might be related to a relatively low atmospheric evaporative demand in this season (e.g., because of a high relative humidity), which would favour sensible heat fluxes rather than latent heat losses at the air-water interface during the day. This effect has been reported in other Spanish waterbodies (Ramos-Fuertes et al., 2016).

There are a number of variables of great interest to the thermal characteristics of Lake Sanabria whose temporal trends are not addressed in this work. Firstly, the wind velocity, which is one of the main variables controlling the turbulent heat transfer to deep waters and the surface evaporative heat loss (e.g., Hondzo \& Stefan, 1993). According to recent reviews, there are no clear evidences of changes in surface wind in Spain, although a slight downward trend (not statistically significant) has been recorded (Vicente-Serrano et al., 2017). Yet, if existent, lower wind velocities over the water surface may reinforce the water column thermal stability and reduce the heat transfer to deep waters.

Besides, water transparency can also play an important role in epilimnetic water heating. Punctual Secchi disc depths comparisons have reported the absence of changes in Sanabria Lake water transparency the last 3 decades (Pahissa et al., 2015; Jambrina-Enríquez et al., 2017), but the analysis of long term continuous datasets would be of interest. Lake water clarity has a complex relationship with water temperature (by means of the shortwave radiation penetration) and bioproductivity, and can also be affected by changes in the catchment rainfall intensity and occurrence.

Finally, changes in snow occurrence (Pons et al., 2009), magnitude and snowmelt patterns related to precipitation and air temperature changes can affect the thermal characteristics of mountainous lakes, such as Sanabria Lake.

Further studies could describe in more detail temporal trends in long term local meteorological data (wind, relative humidity, solar radiation, cloudiness). Besides, a detailed lake and river temperature monitoring coupled with numerical modelling studies could help to understand the uncertainties in the lake thermal trends, mainly related to the heat fluxes at the air-water interface.

\section{CONCLUSIONS}

A dataset of 31 years of Lake Sanabria water temperature profiles helped to better understand the decadal trends in the lake thermal properties, which are essential to contextualize the lake limnology and to better understand its response to global change. The analysis of 27 study variables describing the hydrometeorology, water temperature, thermal stability and stratification period of the lake has led to coherent results but the whole understanding of the processes involved is still incomplete. Surprisingly but with a high statistical significance, Lake Sanabria registers a cooling trend originated by the decrease of bottom and hypolimnetic water temperatures. This result differs from the general European trend of warming inland lakes and can be related to a stronger thermal stratification and changes in the Tera River hydrology. Despite the scarcity of similar lakes or the differences within lakes and reser- 
voirs, equivalent analyses in other Iberian freshwater bodies and numerical modelling exercises will be of great help to better understand their future thermal response to global change.

\section{ACKNOWLEDGEMENTS}

This work was funded by Endesa, S. A. within the project Reservoirs and Climate Change: Contribution to the Climate Change Adaptation Strategy of Endesa Hydropower Facilities. Field data used in this study were provided by the Laboratory of Limnology of the Sanabria Lake Natural Park.

\section{REFERENCES}

AMBROSETTI, W. \& L. BARBANTI. 1999. Deep water warming in lakes: an indicator of climatic change. Journal of Limnology, 58 (1): 1 .

ARMENGOL, J., J. J. RODRÍGUEZ, J. C. GARCÍA, J. ORDOÑEZ \& R. MARCÉ. 2009. La gestión de los embalses en relación a la calidad del agua en condiciones de sequía extrema. Ingeniería del agua, 16 (4): 285-294.

ARVOLA, L., G. GEORGE, D. M. LIVINGSTONE, M. JÄRVINEN, T. BLENCKNER, M. T. DOKULIL, E. JENNINGS, C. N. AONGHUSA, P. NÕGES, T. NÕGES, G. A. WEYHENMEYER, G. GEORGE, D. M. LIVINGSTONE, M. JÄRVINEN, L. ARVOLA, P. NÕGES, T. BLENCKNER, M. T. DOKULIL, G. A. WEYHENMEYER \& T. NÕGES. 2009. The Impact of the Changing Climate on the Thermal Characteristics of Lakes. In: The Impact of Climate Change on European Lakes. 85-101. Springer Netherlands. Dordrecht.

BLADÉ, I. \& Y. CASTRO-DÍEZ. 2010. Tendencias atmosféricas en la Península Ibérica durante el periodo instrumental en el contexto de la variabilidad natural. In: Clima en España: Pasado, presente y futuro. 25-42. Madrid.

CATALAN, J., M. G. BARBIERI, F. BARTUMEUS, P. BITUŠÍK, I. BOTEV, A. BRANCELJ, D. COGALNICEANU, M.
MANCA, A. MARCHETTO, N. OGNJANOVA-RUMENOVA, S. PLA, M. RIERADEVALL, S. SORVARI, E. ŠTEFKOVÁ, E. STUCHLÍK \& M. VENTURA. 2009. Ecological thresholds in European alpine lakes. Freshwater Biology, 54 (12): 2494-2517.

CATALAN, J., S. PLA, M. RIERADEVALL, M. FELIP, M. VENTURA, T. BUCHACA, L. CAMARERO, A. BRANCELJ, P. G. APPLEBY, A. LAMI, J. A. GRYTNES, A. AGUSTII-PANAREDA \& R. THOMPSON. 2002. Lake Redó ecosystem response to an increasing warming the Pyrenees during the twentieth century. Journal of Paleolimnology, 28 (1): 129-145.

DOKULIL, M. T. 2014a. Impact of climate warming on European inland waters. Inland Waters, 4 (1): 27-40.

DOKULIL, M. T. 2014b. Predicting summer surface water temperatures for large Austrian lakes in 2050 under climate change scenarios. Hydrobiologia, 731 (June): 19-29.

ENGELHARDT, C. \& G. KIRILLIN. 2014. Criteria for the onset and breakup of summer lake stratification based on routine temperature measurements. Fundamental and Applied Limnology / Archiv für Hydrobiologie, 184 (3): 183-194.

GIRALT, S., M. T. RICO-HERRERO, J. C. VEGA \& B. L. VALERO-GARCÉS. 2011. Quantitative climate reconstruction linking meteorological, limnological and XRF core scanner datasets: The Lake Sanabria case study, NW Spain. Journal of Paleolimnology, 46 (3): 487-502.

GONZALEZ-HIDALGO, J. C., D. PEÑAANGULO, M. BRUNETTI \& N. CORTESI. 2016. Recent trend in temperature evolution in Spanish mainland (1951-2010): from warming to hiatus. International Journal of Climatology, 36 (6): 2405-2416.

HAMBRIGHT, K. D., M. GOPHEN \& S. SERRUYA. 1994. Influence of long-term climatic changes on the stratification of a subtropical, warm monomictic lake. Limnology and Oceanography, 39 (5): 1233-1242.

HELSEL, D. R. \& R. M. HIRSCH. 2002. Statistical Methods in Water Resources. In: Techniques of Water Resources Investigations, 
Book 4. 522. U.S. Geological Survey.

HENDERSON-SELLERS, B. 1986. Calculating the surface energy balance for lake and reservoir modeling: A review. Reviews of Geophysics, 24 (3): 625.

HILL, J., M. STELLMES, T. UDELHOVEN, A. RÖDER \& S. SOMMER. 2008. Mediterranean desertification and land degradation: Mapping related land use change syndromes based on satellite observations. Global and Planetary Change, 64 (3-4): 146-157.

HONDZO, M. \& H. G. STEFAN. 1993. Regional water temperature characteristics of lakes subjected to climate change. Climatic Change, 24 (3): 187-211.

JAMBRINA-ENRÍQUEZ, M., C. RECIO, J. C. VEGA \& B. VALERO-GARCÉS. 2017. Tracking climate change in oligotrophic mountain lakes: Recent hydrology and productivity synergies in Lago de Sanabria (NW Iberian Peninsula). Science of the Total Environment, 590-591: 579-591.

KRAEMER, B. M., O. ANNEVILLE, S. CHANDRA, M. DIX, E. KUUSISTO, D. M. LIVINGSTONE, A. RIMMER, S. G. SCHLADOW, E. SILOW, L. M. SITOKI, R. TAMATAMAH, Y. VADEBONCOEUR \& P. B. MCINTYRE. 2015. Morphometry and average temperature affect lake stratification responses to climate change. Geophysical Research Letters, 42 (12): 4981-4988.

MAGEE, M. R. \& C. H. WU. 2017. Response of water temperatures and stratification to changing climate in three lakes with different morphometry. Earth System Science, 215194: 6253-6274.

MARCÉ, R., M. À. RODRÍGUEZ-ARIAS, J. C. GARCÍA \& J. ARMENGOL. 2010. El Niño Southern Oscillation and climate trends impact reservoir water quality. Global Change Biology, 16 (10): 2857-2865.

MORÁN-TEJEDA, E., A. CEBALLOS-BARBANCHO, J. M. LLORENTE-PINTO \& J. I. LÓPEZ-MORENO. 2012. Land-cover changes and recent hydrological evolution in the Duero Basin (Spain). Regional Environmental Change, 12 (1): 17-33.

MORÁN-TEJEDA, E., J. I. LÓPEZ-MORENO, A. CEBALLOS-BARBANCHO \& S. M.
VICENTE-SERRANO. 2011. River regimes and recent hydrological changes in the Duero basin (Spain). Journal of Hydrology, 404 (3-4): 241-258.

PAHISSA, J., C. FERNÁNDEZ-ENRÍQUEZ \& C. DE HOYOS. 2015. Water quality of Lake Sanabria according to phytoplankton. A comparison with historical data. Limnetica, 34 (2): 527-540.

PALAU, A. \& C. PRIETO. 2009. Hidroelectricidad, embalses y cambio climático. Ingeniería del agua 16 (4): 311-324.

PONS, M. R., D. SAN-MARTÍN, S. HERRERA \& J. M. GUTIÉRREZ. 2009. Snow trends in Northern Spain: analysis and simulation with statistical downscaling methods. International Journal of Climatology, 30 (12): n/a-n/a.

PRATS RODRÍGUEZ, J., R. MORALES BAQUERO, J. DOLZ RIPOLLÉS \& J. ARMENOL BACHERO. 2014. Aportaciones de la limnología a la gestión de embalses. Ingeniería del agua, 18 (1): 83-97.

RAMOS-FUERTES, A., J. PRATS \& J. DOLZ. 2016. Balances de agua y calor en la marisma de Doñana. Ingeniería del agua, 20 (4): 169.

READ, J. S., D. P. HAMILTON, I. D. JONES, K. MURAOKA, L. A. WINSLOW, R. KROISS, C. H. WU \& E. GAISER. 2011. Derivation of lake mixing and stratification indices from high-resolution lake buoy data. Environmental Modelling \& Software, 26 (11): 1325-1336.

DEL RÍO, S., L. HERRERO, À. PENAS \& by SARA DEL RÍO. 2009. Recent climatic trends in Castilla and León (Spain) and its possible influence on the potential natural vegetation Recent climatic trends in Castilla and León (Spain) and its possible influence on the potential natural vegetation. Acta Botanica Gallica, 156 (4): 625-636.

SABATER, S., V. ACUÑA, R. J. BATALLA, C. BORREGO, A. BUTTURINI, M. FELIP, E. GARCÍA-BERTHOU, S. GASCÓN, R. MARCÉ, E. MARTII, M. MENÉNDEZ, I. MUÑOZ, X. QUINTANA \& F. SABATER. 2016. Ecosistemes aquàtics continentals. In: Tercer informe sobre el canvi climàtic a Catalunya. 237-262. Institut d'Estudis Catalans y Generalitat de Catalunya. Barcelona. 
SAHOO, G. B., A.L. FORREST, S. G. SCHLADOW, J. E. REUTER, R. COATS \& M. DETTINGER. 2016. Climate change impacts on lake thermal dynamics and ecosystem vulnerabilities. Limnology and Oceanography, 61 (2): 496-507.

STAINSBY, E. A., J. G. WINTER, H. JARJANAZI, A. M. PATERSON, D. O. EVANS \& J. D. YOUNG. 2011. Changes in the thermal stability of Lake Simcoe from 1980 to 2008. Journal of Great Lakes Research, 37 (SUPPL. 3): 55-62.

STOCKER, T. F., D. QIN, G.-K. PLATTNER, M. M. B. TIGNOR, S. K. ALLEN, J. BOSCHUNG, A. NAUELS, Y. XIA, V. BEX \& P. M. MIDGLEY. 2013. Climate Change 2013: The Physical Science Basis. Working Group I Contribution to the Fifth Assessment Report of the Intergovernmental Panel on Climate Change. Cambridge University Press. Cambridge, UK.

VEGA, J. C., C. DE HOYOS \& J. J. ALDASO-
RO. 1992. The Sanabria Lake. The largest natural freshwater lake in Spain. Limnetica, 8: 49-57.

VEGA, J. C., C. DE HOYOS, J. J. ALDASORO, J. DE MIGUEL \& H. FRAILE. 2005. Nuevos datos morfométricos para el Lago de Sanabria. Limnetica, 24 (1-2): 115-121.

VICENTE-SERRANO, S. M., E. RODRÍGUEZCAMINO, F. DOMÍNGUEZ-CASTRO, A. EL KENAWY \& C. AZORÍN-MOLINA. 2017. An updated review on recent trends in observational surface atmospheric variables and their extremes over Spain. Cuadernos de Investigación Geográfica, 43 (1): 209.

WETZEL, R. G. \& G. E. LIKENS. 2000. The Heat Budget of Lakes. In: Limnological Analyses. 45-56. Springer New York. New York, NY.

WILLIAMSON, C. E., J. E. SAROS, W. F. VINCENT \& J. P. SMOL. 2009. Lakes and reservoirs as sentinels, integrators, and regulators of climate change. Limnology and Oceanography, 54 (6_part_2): 2273-2282. 